\title{
Controlling female cancer in Argentina. Divergent initiatives and the road to fragmentation
}

\author{
Yolanda Eraso (*) \\ (*) Faculty of Health and Life Sciences, Oxford Brookes University. \\ yolandaeraso@brookes.ac.uk
}

Dynamis

[0211-9536] 2014; 34 (1): 73-99

http://dx.doi.org/10.4321/S0211-95362014000100005
Fecha de recepción: 10 de diciembre de 2012

Fecha de aceptación: 17 de julio de 2013

SUMMARY: 1.-Introduction. 2.-The first cancer institute: Private philanthropy, the league of cancer, and the model of cancer centralisation. 3.-The gynaecology clinic: medical specialisation and the decentralised model of cancer. 4.- Regional initiatives and the road to fragmentation. 5.-Technology and the control of cancer diagnosis. 6.-From local to national (and back again). 7.-Conclusions.

\begin{abstract}
This article analyses the organisation of cancer control in Argentina, with a special focus on the initiatives, institutions, and models that targeted female or gynaecological cancers. It identifies and examines the main factors in the process of elaborating a national policy to control the disease drawing on a series of actors and instruments such as the state, medical professionals, institutions and services, and the use of technology (notably diagnostic tools) for the detection of the disease. It traces the developments in the organisation highlighting its transformations from a centralising to a decentralised model of service provision. Using the concept of «path-dependence» the article examines the continuities and changes observed in the organisation of female cancer critically signalling the particular time at which a path was taken where «fragmentation» became consolidated within the health system. It also argues that it was within the field of cancer diagnosis that Argentinian doctors first sought to create the foundational structures of cancer organisation. The article contends that the path-dependence analytical approach helps us acknowledge the importance of historical analysis in the identification of factors that led to the lack of service coordination, including the persistent strain between national/provincial states that hampered the development of comprehensive programmes, aspects that have continued to mark efforts in the elaboration of cancer policies to the present day.
\end{abstract}

KEY WORDS: cancer organisation, path-dependence, gynaecological cancers, diagnosis, cancer control policies.

PALABRAS CLAVE: organización del cáncer, «dependencia del camino», cáncer ginecológico, diagnóstico, políticas de control del cáncer. 


\section{Introduction $\left(^{*}\right)$}

In recent years, a series of studies focussing on the provision of oncological services in Argentina, and in preventive programmes for breast and cervical cancer in particular, have drawn attention to the need for the development of national strategies to efficiently respond to what the World Health Organisation predicts as an increase in mortality for all cancers ${ }^{1}$. These surveys have returned a rather sombre picture. On the one hand, the provision of health services in Argentina is highly fragmented due to the existence of different providers: the public sector, the trade unions' health insurance (obras sociales), and the private sector, including private insurers and civil society organisations. One the other, such a composite of health care providers means that cancer services and programmes are distributed around various stakeholders which makes the planning and implementation of a comprehensive national programme a challenging goal. Some of these studies have highlighted patterns in the nature of interactions among different stakeholders, for example, civil society organisations have little articulation among them, and their communication with the state is rather poor; while the obras sociales lack incentives to generate primary and secondary preventive programmes ${ }^{2}$. According to Silvina Arrossi, initiatives such as the National Programme for Cervical Cancer Control (1998) suffered from lack of funding and a dedicated team responsible for the articulation and monitoring of activities within each of the country's provinces. Ten years after its implementation, the programme showed great variability in provincial responses in terms of quality control, coverage, health inequalities and resource allocation ${ }^{3}$. This situation seems to come hand in hand with the one observed by the Pan American Health Organisation, which, after analysing epidemiological data and tendencies, disappointingly concluded

$\left({ }^{*}\right)$ Research for this paper was generously funded by a Research Fellowship awarded by the Wellcome Trust (WT082964), United Kingdom.

1. Cancer mortality accounted for 7.6 million deaths (around 13\% of all deaths) in 2008; and it is projected to rise by nearly 13.1 million in 2030. WHO. Cancer, Fact sheet N. ${ }^{\circ} 297$, February 2012; [cited 02 Dec 2012]. Available from: http://www.who.int/mediacentre/factsheets/fs297/ en/index.html

2. Maceira, Daniel; Olavariaga, Sofía. Mapa de actores del sector oncológico en la Argentina. Revista de Salud Pública. 2011 ; 15 (1): 17-28 (21, 24).

3. Arrossi, Silvina. Proyecto para el mejoramiento del Programa Nacional de Prevención de Cáncer de Cuello Uterino en Argentina. Buenos Aires: Organización Panamericana de la Salud, n. ${ }^{\circ}$ $64 ; 2008$, p. 114-115. 
that cervical cancer mortality rates have not significantly improved in Latin America in the last forty years ${ }^{4}$.

Missing in these analyses is a deeper understanding of past interventions, programmes, and policies in female cancer, although there is a superficial awareness of historical continuity in the perceived failure or inability of governments to set up a sustainable preventive programme. This article does not attempt to unravel «the causes of the cause» but it proposes to look in historical perspective at the developments of some of the identified actors within the private and public sector, and the recurring problems (division of services, lack of coordination) in order to bring to the fore core aspects of the foundations of cancer organisation in Argentina. A historical review may start to shed light on some fundamental questions about the main determinants behind certain patterns that resonate in evaluative analysis, such as fragmentation, lack of coordination, failure of policies, and lack of political authority. For the purpose of this paper, I turn to ideas of «pathdependence» as an explorative framework and as an orientation for my enquiry into the history of female cancer organisation, not least because it is a concept increasingly used by scholars of public and social policy to explain phenomena of continuities and change in health care systems. As political scientist Robert Putnam has argued,

«History matters because it is "path dependant": what comes first (even if it was in some sense "accidental") conditions what comes later. Individuals may "choose" their institutions, but they do not choose them under circumstances of their own making, and their choices in turn influence the rules within which their successors choose» ${ }^{5}$.

In this sense, the notion of path-dependence can be a useful tool to investigate what drives change, and what limits or constrains it, in health care policy. In following a historical trajectory of cancer organisation, I identify two different aspects that have shaped its features: the first one remits to a foundational moment that reflects the shaping of actors (and their positions and interactions), institutions and instruments (technology) within the fight against cancer; the second aspect refers to what is called

\footnotetext{
4. Lewis, Merle. A situational analysis of cervical cancer in Latin America \& the Caribbean. Washington: PAHO; 2004.

5. Putnam, Robert; Leonardi, Robert; Nanetti, Raffaella. Making democracy work: Civic traditions in modern Italy. Princeton: Princeton University Press; 1993, p. 8.
} 
in path-dependence the «critical juncture» or «punctuation» ${ }^{6}$, that is, the moment in which a specific path is taken. In this case, I will use the term to refer to a moment when a new mechanism was set in place and in which past foundational elements (actors, policies, ideas, etc.) can find a way of confirmation or rejection.

The actors and instruments I will be concentrating on are the state, medical professionals, institutions, and technology (diagnostic tools). These have allowed me to identify two main features in the organisation of cancer control in Argentina. The first one is that cancer diagnosis, rather than cancer treatment, stood as the main configuring and foundational principle. The second one, later in time, is that a window of opportunity was opened in 1943, when attempts at centralising a national direction for health policies were formulated, and whose resolution set a new path where «fragmentation» became consolidated within the health system. More specifically, I will analyse the role of main actors including philanthropists, social leagues, state authorities, hygienists, and cancer specialists - and their professional rivalries, i.e. gynaecologists vs. «cancerologists». I will also look at the institutional modalities and spaces, such as the specialised centre, the gynaecology clinic and anti-cancerous centres; and finally, the control for diagnosis, through the use of diagnostic tools to detect cervical cancer.

Historical surveys of cancer organisation in industrialised countries, such as those undertaken by Patrice Pinell (France), John Pickstone (Great Britain and the US), Ornella Moscucci (Great Britain), Ton van Helvoort (Germany), have pointed to the differences and specificities of the alliances and trade-offs between medical specialists and non-scientific groups, which led to the configuration of particular forms of cancer services whose main features still have an impact today ${ }^{7}$. In most of these countries medical

6. For an analysis of other uses of this concept see Harrison, Stephen et al. Path dependence, public policy and the National Health Service performance regime. Paper presented to «Policy histories and the National Health Service» workshop, University of Manchester, 24 January 2008. Economic and Social Research Council. Available from: http://www.esrc.ac.uk/my-esrc/ grants/RES-166-25-0051/outputs/Download/eb334abb-cdeb-433e-a3ab-04670896dd0e

7. Pinell, Patrice. The fight against cancer: France 1890-1940. New York: Routledge; 2002; Pickstone, John. Contested cumulations: Configurations of cancer treatments through the twentieth century. Bulletin of the History of Medicine. 2007; 81: 164-196; Moscucci, Ornella. Gender and cancer in Britain, 1860-1910. The emergence of cancer as a public health concern. American Journal of Public Health. 2005; 95 (8): 1312-1321; Helvoort, Ton van. Scalpel or rays? Radiotherapy and the struggle for the cancer patient in pre-second world war Germany. Medical History. 2001; 45: 33-60. 
research devoted to treatments became instrumental in that process. As Pinell has argued for France, «therapeutic efficacy was the prerequisite for "controlling" cancer» ${ }^{8}$. This therapeutic-based approach characterised industrialised countries' initiatives until the end of the Second World War, when a more preventive approach started to be developed, especially through secondary prevention and the organisation of screening programmes for cervical cancer first and mammography later.

Initiatives for controlling cancer in Latin American countries ${ }^{9}$, and Argentina in particularly, indicates a rather different story. During the first decades of the twentieth century, cancer treatments tended to incorporate the advances in radiotherapy developed at international leading centres, especially the Curie Foundation in Paris. With few exceptions, there was little scope for basic research, mainly because unlike countries such as France, the US and the UK, South America countries lacked a national financing body exclusively devoted to cancer research. As this paper will argue, it was within the field of cancer diagnosis where Argentinian doctors first sought to create the foundational structures of cancer organisation.

\section{The first cancer institute: Private philanthropy, the league of cancer, and the model of cancer centralisation}

The Institute of Experimental Medicine for the Study and Treatment of Cancer (IEM) opened in Buenos Aires in November 1922, under the leadership of pathologist Dr Ángel Honorio Roffo (1882-1947). Its commencement was preceded by months of intense discussions and debates (including a failed inauguration in April), which was covered extensively in the national press. At the centre of the dispute was the institute's affiliation to one of the two main academic spaces of the time, the Faculty of Medicine of the National University of Buenos Aires, and the National Academy of Medicine, nominally dependant of the university but with a great deal of power and autonomy. Initially planned and designed by the Academy — which also secured the funds from the Parliament for its building, the IEM became,

\footnotetext{
8. Pinell, Patrice. Cancer. In: Cooter, Roger; Pickstone, John, eds. Companion to medicine in the twentieth century. London and New York: Routdledge; 2003, p. 671-686 (676).

9. For the Brazilian case see Teixeira, Luiz. O controle do câncer no Brasil na primeira metade do século XX. História, Ciências, Saúde-Manguinhos. 2010; 17 (suppl.1): 13-31.
} 
as it approached its inauguration, administratively controlled by the Faculty of Medicine, while the Academy was completely excluded from its running ${ }^{10}$. Yet despite of the heated debates about which institution should oversee the administrative and technical activities of the IEM, soon after its inauguration it became clear that it was the institute's director, $\mathrm{Dr}$ Roffo, who was the leader and the linchpin of the IEM until 1946 when the institute was intervened and its director replaced. During these highlyprofiled jurisdictional conflicts neither of the contenders (University and Academy) disputed Roffo's appointment as the IEM's director, although conflicts with the University loomed large as Roffo attempted to expand his leadership in the fight against cancer. And while there is no doubt that Roffo was at the time the country's most important research authority in cancer, it is also the case, as this article will argue, that his political ability, lobbying capacity, controlling personality and highly-ambitious drive in becoming the only referent in the fight against cancer in Argentina will frame the disputes with the Faculty of Medicine in the years to come and, to some extent, will shape the future of cancer organisation.

In the twenties Roffo became engaged in the creation of several influential organisations that variously supported and gravitated around the work of the IEM. He instigated, along with his wife, the foundation of the Argentine League for the Fight Against Cancer (1921), and created and presided over: the Argentine Society for the Study of Cancer (1924); the main journal of the specialty, the Boletin del Instituto de Medicina Experimental para el Estudio y Tratamiento del Cáncer; the first School of Nurses specialised in cancer (1924); and the Latin American Confederation for the Study of Cancer (1929). All these institutions rapidly promoted the association of Roffo with cancer in Argentina, and more importantly, they also reflected the orientation of the IEM as a specialised cancer institute with a three-fold

10. The IEM was in fact inaugurated twice, first in April 1922 by the Academy, and then again in November of that year. The conflict was prolonged until 1925 when the Parliament finally granted the National Academy of Medicine status as an independent institution. For a detailed analysis of the conflicts between the Academy and the Faculty of Medicine see Buschini, José. Emergencia y desarrollo de las investigaciones sobre el cáncer en la Argentina: Marcos institucionales, trayectorias profesionales y prácticas, 1909-1983. [Tesis doctoral] Flacso. Sede Académica Argentina; 2010, especially chapter 2. Available from: www.flacsoandes.org/dspace/ handle/10469/2682 
basis: medical research, medical diagnosis and treatment, and social work ${ }^{11}$. Such a concentration of distinct activities in a single institution became the hallmark of the IEM and provided a model for cancer organisation whose attributes drew a great deal of international attention.

Indeed, the IEM became the first specialised institute in Latin America and one of the first cancer institutes in the world, a list that early in the twenties, only included Germany, Sweden, Spain, France, the Netherlands, the United States and the United Kingdom. During its first year in operation, the IEM was regularly visited by prominent cancer specialists from the Americas and Europe, who came attracted by both the peculiarities of its organisation and Roffo's growing international prestige as experimental researcher. Thus, the Argentine institute was soon associated with, and enjoyed the status of, a «model institution». In this sense, are instructive the impressions left by one of its many visitors, Dr Paolo Pietra from the University of Turin, who came to the IEM in 1925 on an official visit to assess its performance and to seek inspiration for the organisation of the first cancer institute in Italy. Amongst the things that drew the attention of the Italian specialist was the IEM's «sanitary orientation, that is absent in the institutes of other nations where unilateral tendencies prevail» ${ }^{12}$. The latter refereed to the tendency of creating separate institutions for each of the different sections that made up the fight against cancer, namely, a centre for diagnosis, a centre for radiotherapy, a hospital for incurables, and centres for experimental research. In the Argentinian case, all these areas appeared as centralised and coordinated by a unique direction. Paradoxically, these organisational aspects that in the twenties and thirties most intrigued foreign visitors were the ones that only few decades later in Argentina would seem impossible to achieve: the coordination of cancer sectors and the centralisation in the process of policy-making.

Underlying the «magnificence» and the uniqueness of the IME's organisation was Roffo's skills in gaining political and economic support from both the public and the private sectors, especially philanthropists, who soon became an instrumental actor in positioning the disease in the public agenda. The IEM was initially inaugurated with a pavilion for diagnosis and

11. Casella, Edgardo. La lucha contra el cáncer en la República Argentina. Boletín de la Oficina Sanitaria Panamericana. 1930; 9 (3): 241-256.

12. Pietra, Paolo. La organización Argentina de la lucha contra el cáncer. Revista Médica de Cuyo «Vox Medica». 1927; 4 (40): 31-38 (37). 
clinical services, and with a capacity of 100 beds. A year later, in 1923, the Research Pavilion «Emilio J. Costa» was inaugurated, donated by a lady from a wealthy Buenos Aires family, Mrs Francisca Buero de Costa, whose son Emilio had died of cancer and to whom she dedicated this pavilion specifically devoted to experimental research and radiological treatment. Remarkably, this was the first time that private philanthropy had funded scientific research in Argentina, and marked a change in the philanthropic culture - until then only directed toward diseases of the poor - that stemmed from the awareness that cancer was a disease that struck all classes alike. Another son of Mrs Buero, Dr Luis Costa, contributed two machines for deep radiotherapy, and equipment for physiotherapy and diathermia. The new pavilion housed in the ground floor, a large teaching room and two separated areas distributed along two wings: in the right one, the laboratories for different sections (experimental medicine, biological clinic, tissue culture, and experimental therapy); and on the left wing, the radiotherapy section with equipment for diagnosis and treatment (roentgen, radium therapy and diathermy). In the first floor, facilities included a library, a photography section, an archive and museum, and laboratories of chemistry, biology and histology ${ }^{13}$. On the occasion of its inauguration, Roffo justified the IEM's organising principles by stating:

«It is inconceivable a hospital for cancer sufferers that is only destined to clinical observation or to the surgical treatment, as it is also inconceivable an institute destined to physical treatments or only destined to scientific speculation. It is crucial to integrate the different activities of laboratory and the clinic in order to benefit as a whole from their experiences instead of having them wasted in an isolated form. It is in this sense that the Institute of Experimental Medicine should be considered as unique of its kind» ${ }^{14}$.

The delivery of such a multi-disciplinary approach to cancer was also possible thanks to the considerable social and economic support of a cancer league, as it was observed in industrialised countries at the time ${ }^{15}$. In July

13. Roffo, Ángel. Pabellón de investigaciones «Emilio J. Costa». Buenos Aires: Imprenta de la Universidad; 1923. In addition, another member of the Costa family contributed technical equipment for the lecture theatre.

14. Roffo, n. 13, p. 37

15. For the case of France, USA, and Britain see Pinell, n. 7; Patterson, James. The Dread Disease: cancer and modern American culture. Cambridge: Harvard University Press; 1987; Austoker, 
1921 Dr Roffo's wife, Elena Larroque de Roffo, founded along with a group of women the "Argentine League for the Fight Against Cancer», LALCEC as it became known in Spanish. The league was inspired by the French Anti-Cancer League, an organisation that the Roffos had the opportunity to observe in Paris, during their academic visit between 1919 and 1920. Yet the similarities with the French league were certainly reduced only to the female charitable branch of the organisation, as the former was, as Pinell has showed ${ }^{16}$, characterised by the alliance of various partners (sanitarists, radiotherapists, surgeons, researchers and philanthropists), which were absent in the Argentinian case. More specifically, LALCEC drew on a wellestablished tradition in the provision of health and welfare in Argentina, the one delivered by female charitable groups. Since the nineteen century, women's voluntarism and philanthropic activities facilitated, financed, and administered (with public and private funds) most of the institutes, asylums, hospitals, and sanitary services dedicated to women, children and the elderly, and so it came as no surprise that a cancer league was also created within this century-long tradition ${ }^{17}$. Cancer, however, was a special disease, which unlike tuberculosis, venereal disease, alcoholism, or infant mortality was not associated with poverty, not so much with age, and crucially, its treatment required very expensive equipment (radium) whose purchase and allocation became a matter for governments. Despite the many differences with the role that charitable and beneficent groups had at the time - notably the cancer league had never run a specialised institute- women's tradition in the provision of welfare became instrumental too in the shaping of cancer control, and it still continues to occupy an important role: With more than a hundred branches, LALCEC is, today, the most important civil society organisation in the fight against cancer ${ }^{18}$.

Back in the twenties, the aims of the league were three-fold: to contribute resources for research and the dissemination of cancer knowledge

Joan. A History of the Imperial Cancer Research Fund 1902-1986. Oxford: Oxford University Press; 1988.

16. Pinell, n. 7, chapter 4.

17. On women's voluntarism and the provision of welfare see Guy, Donna. Women build the Welfare State: Performing charity and creating rights in Argentina, 1880-1955. Durham: Duke University Press; 2009; Eraso, Yolanda, comp. Mujeres y asistencia social en Latinoamérica, siglos XIX y XX. Argentina, Colombia, México, Perú y Uruguay. Córdoba: Alción Editora; 2009.

18. On the institutional organisation of LALCEC today see its website. Available from: http://www. lalcec.org.ar/quienessomos.html 
in order to promote the early detection of the disease; to be an organ of public education through the propagation of elemental notions; and to collaborate with the assistance of cancer patients at the IEM and at home. "Cancer is curable as long as it is a local disease» was the first slogan that LALCEC introduced into the public ${ }^{19}$. The close association of the league with the IEM can be hinted through its rules, which established the IEM's director as LALCEC's scientific advisor, and the transfer to the former of any remaining goods in the event the league were dissolved. The rules also planned the setting up of subcommittees across the country to attend the needs of the local populations, and included a financial contribution to the central committee in Buenos Aires intended to support the assistance of patients from the provinces that were treated at the IEM ${ }^{20}$.

Soon after the inauguration of the IEM, Roffo persuaded LALCEC members, through his wife who was then President, that the first mission of the league was to raise funds for the building of a women's pavilion for in-patients with a hundred-bed capacity. The league swiftly responded to the call and after fundraising a considerable sum started the works on the building. However, as funds run short, Roffo resorted to his connections with private philanthropy, in this case, an old friendship with an elite family, the Solari family, whose important donation allowed for the completion of the works. This gift was channelled through LALCEC, probably an attempt of Roffo to reinforce the league's dependence to his persona, a position that, after Mrs Larroque's sudden death in 1924 and as the league grew, its board of women would not be so keen to endorse. In 1928, the women's pavilion was formally donated by LALCEC to the IEM and opened to the public. The new building offered wards with thirteen and seven beds, one smaller room with three beds; and four rooms with one bed each for terminally-ill patients. It also had a gynaecology ward ${ }^{21}$.

Between 1938 and 1939 Roffo inaugurated the last two pavilions that made up the core group of buildings of the IEM. The first one was the pavilion «Dr Luis Costa Buero», funded with a bequest left by the homonymous doctor, whose family thus became the mayor philanthropist

19. Estatutos de la Liga Argentina de Lucha contra el Cáncer. Buenos Aires: s.e.; 1936, p. 5.

20. See «XII De los Subcomites» in Estatutos, n. 19, p. 14.

21. Inauguración del nuevo Pabellón para Mujeres. Donado por la Liga Argentina de la Lucha contra el cáncer el 12 de enero de 1928. Buenos Aires: Imprenta de la Universidad, 1928. 
in the history of the institute 22 . The six-storey pavilion had a capacity for a hundred beds, and its lay-out introduced innovations into the spatial organisation of the wards as its 50 rooms only accommodated two beds each, thus eliminating the negative impressions that large common wards generated in patients ${ }^{23}$. The second building, named the «Model pavilion», was funded by the national government, and it had an increased capacity of around 250 beds and two state-of-the-art operation theatres ${ }^{24}$.

At the time of this institutional expansion, the IEM was separated from the administrative dependence of the Faculty of Medicine, a situation that took place «without giving any reason», as stated by a report from the auditors of the IEM's intervention in $1946^{25}$. From that date on the institute was returned to the Faculty. As we will see next, Roffo's centralising model of cancer organisation encountered in the thirties its main opponents who mostly came from a new type of cancer specialists, the gynaecologists.

\section{The gynaecology clinic: medical specialisation and the decentralised model of cancer}

The most important university gynaecology clinic in Buenos Aires was located at the «Hospital de Clínicas», the leading teaching hospital of the Faculty of Medicine. Between the twenties and thirties, the clinic completely renewed its facilities by increasing the number of beds and the setting up of new wards, and by creating laboratories and services with new radiotherapy equipment. As the newly appointed director, Dr Juan Carlos Ahumada expressed in his inaugural speech as Chair,

«by the end of 1933, the old gynaecological clinic has completely changed its appearance and it has been transformed into a small Institute where

22. In 1934, the Buero family also donated the funds to build a chapel in the institute. Notas Varias. Boletín del Instituto de Medicina Experimental para el Estudio y Tratamiento del Cáncer. 1934; 12 (39): 217-218.

23. Roffo, Ángel. Discurso inauguración Pabellón «Luis Costa». Boletín del Instituto de Medicina Experimental para el Estudio y Tratamiento del Cáncer. 1938; 15 (47): 244-247.

24. Roffo, Ángel. Discurso inauguración Pabellón modelo. Boletín del Instituto de Medicina Experimental para el Estudio y Tratamiento del Cáncer. 1939; 16 (52): 124-126.

25. Archivo de la Facultad de Medicina, Universidad de Buenos Aires. File 10099/I/946, 21 August 1946. Instituto de Medicina Experimental para el Estudio y Tratamiento del Cáncer. Folder 30.742, vol. 1 1922-1953. 
gynaecology can be studied in its three core aspects: clinical, therapeutic and experimental» 26 .

Indeed, with a capacity of 65 beds and out-patient consulting rooms, the clinic offered a remarkable variety of specialist services, among them, roentgen and radiotherapy, odontology, dermatology, endocrinology, laboratories for pathology and clinical analysis, a section for experimental medicine (with a plant nursery), teaching and scientific facilities (museum, library, and a seminar series), and social services (with a professional social worker $)^{27}$. For almost a decade (1925-34) Ahumada had been the head of «curietherapy service» (name taken form the French to indicate the treatment with radium) at the prestigious «Hospital Rivadavia», the main women's hospital. It is interesting to see that during Ahumada's professional trajectory as a surgeon he became familiar with the possibilities that radiotherapy was offering to gynaecological tumours, especially for the treatment of cervical cancer.

It is not surprising that Ahumada became a staunch defender of gynaecology as the latter developed into a fully-fledged specialised discipline, and as such, one capable of dealing with gynaecological cancers. He argued that the Chair had three main duties to fulfil: teaching, research, and to lead the clinic, and excited about the developments in endocrinology, he pleaded for «the transformation of the clinician into an experimental researcher ${ }^{28}$. Thus, this «small institute» chaired by a gynaecologist with a clear vision for the role of his speciality and who regarded its progresses as deserving an outstanding place within the medical field, would leave little chance to the initiatives formulated by a cancerologist (like Roffo) to take the lead in the control of gynaecological cancers.

As the thirties progressed, cancer care was increasingly embraced by local authorities who began to see it as a part of the broader public health concerns. The Municipality of Buenos Aires created specialised radiotherapy centres, such as the «Instituto Municipal de Radiología y Fisioterapia» (1931) with services of radium therapy and radiotherapy, and directly financed (Ramos Mejía Hospital) and subsidised (Rivadavia Hospital) services for

\footnotetext{
26. Ahumada, Juan Carlos. Conferencia inaugural de la cátedra de Clínica Ginecológica. La Prensa Médica Argentina. 1935; 22 (21): 987-995 (992).

27. Ahumada, n. 26; p. 992.

28. Ahumada, n. 26, p. 995
} 
cancer diagnosis and treatment within general hospitals. The latter was a private-public charity hospital administered by the prestigious female charitable group, the Society of the Lady of Beneficence of the Federal Capital, with subsidies of national and local governments ${ }^{29}$. In 1935 gynaecologist Dr Adrián Bengolea created an «Anti-cancerous centre» within the Rivadavia Hospital. Bengolea, who was director of the hospital (1936-1946), became one of Roffo's main opponents as he grew adamant against the IEM's attempts at centralising the provision of cancer services. He elaborated a counter-plan, which he termed, «a rational plan for the fight against cancer», whose principles he published in different journals and presented at the Faculty of Medicine of the country's main universities. In one of these conferences, in Córdoba, Bengolea argued that «cancer is a curable disease» provided it was detected before the stage of «metastasis and invasion». For him, doctors' ignorance and fatal mistakes in diagnosis, alongside the general lack of knowledge in the public were the main problems that hindered the early detection of the disease. But so was too the lack of state support in the provision of services except for the setting up of a «magnificent centre for experimental research» (a clear allusion to the IEM). In this sense, Bengolea had serious reservations about the IEM's organisation, and above all, Roffo's skills to deal with a highly specialised area of medicine like gynaecology,

«It is not the same to rub the abdomen or the ear of a rat to establish the appearance of an experimental cancer than to perform a surgical procedure full of difficulties to save a human life» ${ }^{30}$.

He ironically referred to Roffo's scientific achievements and international reputation in the area of experimental cancer, most notably, for pioneering the identification of carcinogenic components of tobacco that led him to establish a relationship between smoking and cancers, which he demonstrated by rubbing tar onto the ears of rabbits ${ }^{31}$. For Bengolea, however, the field of

29. Bengolea, Adrián. Memoria anual elevada por la dirección del Hospital Rivadavia a la Sociedad de Beneficencia de la Capital. Revista Médico Quirúrgica de Patología Femenina. 1938; 11: 248-258.

30. Bengolea, Adrián. El problema del cáncer en su aspecto médico-social. Revista Médico Quirúrgica de Patología Femenina. 1935; 6: 603-621 (604).

31. Roffo, Ángel. Desarrollo de un carcinoma en el conejo por el tabaco. Boletín del Instituto de Medicina Experimental para el Estudio y Tratamiento del Cáncer. 1930; 7 (24): 501-510. 
experimental carcinogenesis should be completely separated from that of cancer diagnosis and treatment. In a conference at the Faculty of Medicine in Rosario, he vigorously stated,

«it is ridiculous to centralise the fight against cancer, because that is to aim for an impossibility, since it is not acceptable that only one institution aspires to carry the medical record of every cancer patient in the country, then treat them, then follow them up, and at the same time develop an effective work of popular education and awareness» ${ }^{32}$.

He proposed that the anti-cancerous centres should only concentrate on the medical and social assistance of cancer that, in his view, was therapeutic (diagnosis and treatment), cultural (education) and social (assistance of incurables $)^{33}$. More importantly, this idea was soon embraced in some of the provincial cities where a pre-existent university gynaecology clinic became an anti-cancerous centre of certain complexity, such as the case of Rosario (Hospital Centenario) in 1938, which offered radium and roentgen treatment alongside the surgical service. In Córdoba, on the other hand, it was the head of the University's gynaecology clinic, Dr Humberto Dionisi, who was appointed by the Faculty of Medicine to organise the fight against cancer in the province. As a result, Dionisi created and directed the «Institute of Cancer» (1942) within the «Hospital de Clínicas» (the University teaching hospital), with out-patient consulting rooms and a ward with 18 beds for lying-in patients. Remarkably, and despite of its name, the institute was mainly intended for the assistance of gynaecological cancer ${ }^{34}$.

The gynaecology clinic within university hospitals alongside the semipublic charitable hospital with strong connections to the Faculty's medical elite, started to articulate an independent site for the fight against cancer ${ }^{35}$. This model of cancer organisation, however, was not born out of a coordinated

32. Bengolea, Adrián. Consideraciones clínicas y terapéuticas sobre el carcinoma de cuello uterino. Revista Médica del Rosario. 1936; 26 (9): 787-802 (801).

33. Bengolea, n. 30, p. 618-620.

34. Dionisi, Humberto. Antecedentes, títulos y trabajos presentados para optar al cargo de profesor titular de clínica ginecológica. Córdoba: Imprenta de la Universidad; 1956, p. 25-26.

35. For the association of breast cancer with the gynaecology clinic see Eraso, Yolanda. Género, feminidad y cáncer de mama. Perspectivas comparadas en Norte y Sudamérica. In: Rustoyburu, Cecilia; Cepeda, Agustina, eds. De las hormonas sexuadas al Viagra. Ciencia, Medicina y Sexualidad en Argentina y Brasil. Mar del Plata: Editorial de la Universidad de Mar del Plata (forthcoming, 2013). 
or planned strategy. It rather was the result of the specialisation attained by the discipline, the international attention given to female cancers in particular - as they became strongly associated with the disease- and as a local reaction to Roffo's centralising model. In the next section, I will focus in more detail in how these actors strove for outlining the fight against cancer through specific policies.

\section{Regional initiatives and the road to fragmentation}

In 1926 Roffo launched what he called a «regional plan for the fight against cancer» across the country. His proposal was approved by prominent hygienist Dr Gregorio Aráoz Alfaro, then director of the National Department of Hygiene (NDH), the main health and sanitary office of the Ministry of Interior ${ }^{36}$. As a member of the Academy, Aráoz Alfaro had participated in the power struggles surrounding the fight against cancer when the conflict sparked off between his institution and the Faculty. As such, we may assume that the director of the NDH had perhaps fewer reservations in supporting the expansion of the IEM at national level than the University might have had. Arguably, one of the most striking aspects of this plan is that it was designed along the lines of the hygienist thought, that is, the sanitary structures and the strategies for controlling infectious diseases. And despite the fact that cancer was not considered at the time an infectious disease, the structure of the proposed sanitary post would not be capable of dealing with the exigencies posed by cancer diagnosis (specialised training in pathology) let alone treatment (costly equipment, and specialised surgery).

Let us examine the proposal in more detail to understand the incompatibilities of the hygienist structures with the ones introduced by the control of cancer. Cancer care would become regionalised along the lines of the NDH's four sanitary posts that existed in each of the country's main regions: north (Tucumán), east (Rosario), west (San Luis), and south (Bahía Blanca). Each of these regions would be responsible for the collection of tissue samples and blood tests from patients, and would be later sent to the IEM in Buenos Aires for analysis and diagnosis. In this way, Roffo

36. Roffo, Ángel. Organización de la lucha regional contra el cáncer. Revista Médica de Cuyo «Vox Medica». 1927; 4 (39): 7-11. 
attempted to centralise diagnosis and, subsequently, indicate the course of treatment from his institute, which in this way acted as a hub for cancer control. Such an ambitious initiative to monopolise the control of cancer was grounded firstly, in the importance of early diagnosis, and secondly, in the need to deter advanced-stage patients from travelling to the IEM in search for (an improbable) cure ${ }^{37}$. Unlike the proposals of Roffo's peers in France, for example, which the Argentinian knew very well, in particular the initiative of Claudius Ragaud who spearheaded a plan for regional «large well-equipped centres devoted to both scientific research and to practical application ${ }^{38}$, Roffo's plan never intended to create a network (or at least a handful) of specialised centres for the treatment of the disease. The concentration on his unique authority of both diagnosis and treatment was, as his contemporaries often repeated, rather chimeric.

At this juncture, two different factors can be identified in the impossibility of materialising a national cancer policy. The first one seems to lie in Roffo's controlling personality, of which one of his collaborators at the IEM, offers us a glimpse when he commented in the peculiar way in which the economy of the institute was run, «by [Roffo] appreciating the minimal detail in everyday life, controlling the package of cotton, the dressing piece, the litter of alcohol, and the gas valve that was opened unnecessarily» ${ }^{39}$. The second factor relates to the political difficulties in setting up an agreement amongst provincial representatives at the National Parliament to pass a federal law with an overarching institutional framework in the fight against cancer. I shall return to this point later.

Roffo's regional plan did, however, find in the thirties, a way of implementation, although it did not count on the support of the NDH but on local provincial and municipal authorities. This initiated in turn a complicated history of uncoordinated and disjointed initiatives that seriously affected the future cohesion of national planning. And although we may argue that this perceived lack of articulation in the proposals formulated from different actors were also observed at the time in countries such as Germany, Britain and France, we can also argue that such situations came to a halt after the foundations of national health care systems were laid

\footnotetext{
37. Roffo, n. 36, p. 7, 10.

38. Regaud, Claudius (1925) quoted in Pinell, n. 7, p. 114.

39. Basso, Juan. 25 Aniversario de la publicación del primer trabajo de medicina experimental del doctor Ángel H. Roffo. Revista Médica de Cuyo «Vox Medica». 1931; 6 (69-70): 33-44 (42).
} 
down post 1945. And as I will discuss later, when a window of opportunity was opened in Argentina around the same time, the path taken endorsed, to a great extent, continuity with the past and, in so doing, it ensured the road to fragmentation.

In 1936, Roffo created the first «Anti-cancerous Dispensary» (dispensario anticanceroso) in the city of Bahía Blanca in the south of the province of Buenos Aires to serve the southern population of the country. This was followed by the organisation of anti-cancerous dispensaries in other cities of the remaining main regions: Rosario (1937) and Paraná (1937) in the east; San Juan (1939) in the west; and Tucumán (1941) in the north. Following Roffo's initial plan of 1926, the dispensaries were created as «branches» of the IEM, dependant of the University of Buenos Aires with directors nominated by Roffo, financed with subsidies from the local governments, and donations and support (social assistance) from the LALCEC branches as the league was extending its presence across the country. As commented before, the role of these dispensaries was to increase the number of cases diagnosed early, and to contain the demand of patients seeking (unnecessary) treatment in the Federal Capital. Yet the inconsistencies observed in relation to the responsibility of those dispensaries, the clear division between the (technical and administrative) direction from the IEM and the economic dependence from the local authorities laid bare a shaky structure. Not least in a place with an influential Faculty of Medicine like Rosario, for example, where cancer specialists were virtually ignored from the design of the dispensary, which reinforced in turn, the immediate response of local initiatives, i.e. the creation of an Anti-cancerous centre (gynaecology clinic), and a «Cancer Society» within the Medical Circle (1937) ${ }^{40}$.

\section{Technology and the control of cancer diagnosis}

Throughout the different initiatives and plans for the delineation of a cancer control programme it became evident that it was diagnosis, rather than treatment, that was the main concern for the specialists involved in its formulation. On the one hand, nobody disputed the dogma of «early diagnosis» as it encapsulated the chance of curing from the disease. On the 
other, there were centres for diagnosis, rather than centres for treatment, the ones that filled the proposals of pathologists, surgeons and gynaecologists as they struggled to draw the attention of health authorities as legitimate actors in the fight against the disease. I shall return to this point later.

Various scholars focussing on the history of female cancer have pointed some significant therapeutic outcomes that lay at the core of the cancer control message, i.e. «early diagnosis» and "prompt treatment»: from preventive breast and cervical radical surgery for precancerous lesions to prophylactic surgery in the case of breast cancer genetic risk ${ }^{41}$. Here, I contend that the use of diagnostic techniques could also have been instrumental in delineating a model of cancer control at the time of the first organisational initiatives.

In the thirties, two different approaches competed for dominance in this field, especially in the case of cervical cancer: Roffo's serum test to detect the presence of tumours, and gynaecologists' use of the colposcope to detect precancerous lesions. As a pathologist, Roffo took special care of the diagnostic aspects of cancer, and pursued this with some degree of obsession. On the one hand, he personally performed the biopsies of every cancer patient admitted to the IEM and proposed, somehow unrealistically, that the IEM became the main histological laboratory of the country. On the other hand, and as an accomplished experimental researcher, he developed a diagnostic test for cancer that was intended for clinical use, easy to perform and effective in its results. The test was presented in 1925 and it became known as «Roffo's reaction». It consisted of the observation of the chemical changes in the blood which took place after adding a solution of neutral red to the serum of patients collected under paraffin. The appearance of a red tint confirmed the existence of a tumour - because of the absorption capacity of $\mathrm{CO} 2$ by the neoplastic cell- while a yellowish hue indicated the absence of cancer ${ }^{42}$.

A test able to satisfy that magic approach to the dreadful disease was one of Roffo's main endeavours, although he was not an exception as other

41. Lerner, Barron. The breast cancer wars: Hope, fear, and the pursuit of a cure in twentieth-century America. New York: Oxford University Press; 2001; Aronowitz, Robert. Unnatural history: Breast cancer and American society. Cambridge: Cambridge University Press; 2007; Bryder, Linda. Women's bodies and medical science: An inquiry into cervical cancer. Basingstoke: Palgrave Macmillan; 2010; Löwy, llana. Preventive strikes. Women, precancer, and prophilactic surgery. Baltimore: John Hopkins University Press; 2010.

42. Roffo, Ángel. La reacción del rojo neutro en presencia del suero normal y con tumor. Revista de la Universidad de Buenos Aires. 1925; 2. ápoca, 3 (4): 367-370. 
similar tests based on chemical changes in the urine, blood, and secretions were designed at the time, most notably, the Botelho's test in France, against which the one of Roffo was often compared. An article published by the IEM doctor, Antonio Gandolfo, in the American Journal of Cancer in 1934, provides insight on how much international attention cancerologists paid to examine the efficiency of Roffo's test ${ }^{43}$. Whilst the international scientific community did not offer conclusive evidence about the value of the test, at the IEM it was routinely applied as part of the admission protocol to all patients arriving at the institute. The latter consisted of a clinical examination, followed by the assessment by a specialist on the organ-site of the disease, alongside a blood extraction (Roffo's test) and a biopsy. In forty-eight hours the patient was asked to return for a definitive diagnosis and course of treatment.

For the purpose of this article, it is interesting to see how the diagnostic test performed for gynaecological cancers. Amongst the several articles published during this period, one that stands out was one authored by a doctor of the institute in 1942, who reviewed the previous studies on the test over a sample size of around 37,000 patients. He concluded that the test's sensitivity varied according to the location of the tumour between a $96 \%$ and $60 \%$. For cancers of the gynaecologic tract, the results were $81.19 \%$ of positives in 3,781 confirmed cases; and for breast cancer, $76 \%$ of positives in 2,797 cases $^{44}$. Doctors at the IEM alleged that the test produced better results in detecting tumours of the internal organs, which were thought to be the most difficult to diagnose as opposed to those easy to reach like the tongue, skin, and lips. Their enthusiasm, however, was often encountered with resistance. At national level, the test was not used outside the IEM, while at international level its value became scrutinized along with those of other cancerologists whose tests lacked specificity and sensitivity. In a thorough review of the value of diagnostic tests published in 1950, the American-based oncologist Freddy Homburger considered quite categorically that Roffo's reaction «has been the subject of considerable controversy, since

43. Gandolfo, Antonio. Roffo's test in cancer. Statistical results of 11.000 cases. American Journal of Cancer. 1934; 22: 363-377.

44. Stuckert, Guillermo. La reacción Roffo en 36.961 enfermos. Resultados estadísticos y clínicos. Boletín del Instituto de Medicina Experimental para el Estudio y Tratamiento del Cáncer. 1942; 19 (60): $629-643$ (633). The article also reported a percentage of test specificity of $83.99 \%$ over 16,341 no-cancer patients. 
most authors who did not belong to Roffo's Institute obtained inconclusive results, although Roffo's pupils accumulated thousands of correctly positive tests» ${ }^{45}$.

Contrary to the lack of specificity of the test routinely used at the IEM, gynaecology clinics offered a very different technique to the early diagnosis of cervical cancer. In this case, the detection of precancerous lesions was made possible by the technique of colposcopy, a procedure for the visual inspection of the cervix that uses binoculars (with multiple magnification) placed on a tripod, and with an attached light source that facilitates the observation of the area. The colposcope was designed by the German Dr Hans Hinselmann in 1925, who also enhanced the colposcopic view of abnormal epithelium by staining the cervix with acetic acid (which turned white the abnormal cells) and with the use of the Schiller test (1928), which applied iodine solution to contrast the images of potential abnormal cells ${ }^{46}$. Soon after its inception, the technique of colposcopy was disseminated to Argentina and Brazil thanks to the medical specialisation that South American doctors carried out at European clinics, where a handful of gynaecologists trained directly with Hinselmann at his clinic in Hamburg ${ }^{47}$.

In 1928, Dr Ahumada introduced the first colposcope into clinical practice, and fairly swiftly other clinics followed suit. Amongst them, were the one at the Institute of Maternity (adjacent to the Rivadavia Hospital), and the one located at the Sardá Maternity both dependant of the Society of Beneficence of the Federal Capital. More importantly, in the latter, Dr Alfredo Jakob initiated in 1934 the routine colposcopic examination of all women assisted in the out-patient consulting rooms. He also offered training courses where many gynaecologists from South America learnt the technique. In this sense, colposcopy, along with Hinselmann's classification of precancerous lesions, found enthusiastic supporters amongst Buenos Aires' gynaecologists, who were eager to demonstrate their expertise and contribution to a disease that they claimed was rightly under the scope of their specialty. In fact, colposcopy became in Argentina the first screening

\footnotetext{
45. Homburger, Freddy. Evaluation of diagnostic tests for cancer. Cancer. 1950; 3 (1):143-172 (154).

46. Iodine solution turned normal epithelium darkish brown because of the reaction of glycogen contained in the cells in contact with the substance, while atypical (benign or malignant) lesions remain unstained or white as they are glycogen deficient.

47. Eraso, Yolanda. Migrating techniques, multiplying diagnoses: The contribution of Argentina and Brazil to early «detection policy» in cervical cancer. História, Ciências, Saúde-Manguinhos. 2010; 17 (suppl. 1): 33-51.
} 
method of asymptomatic women before the Pap smear test entered the clinic. Colposcopy also provided gynaecologists with a new specialisation, that of colposcopist, for which they largely became internationally renowned. Arguably, mastering the technique conferred gynaecologists with an almost missionary zeal in the crusade for «early diagnosis» and a great deal of confidence (not least because of its technological precision) an attitude that was similarly observed in Brazil as well as in other latitudes where colposcopy was introduced, such as Oceania ${ }^{48}$.

In contraposition, the approach offered by Roffo at the IEM was, as we have seen, quite different. Despite the fact that between 1931 and 1943 cervical cancer occupied the third place in the statistics of cancer morbidity at the institute, its director was unimpressed by the possibilities offered by the new detecting technology. By 1943 he explained that although a colposcope was acquired by the institute some years earlier, he was not keen on the technique, or with the use of the Schiller test. He commented rather contemptuously, that «the use of the colposcope occupies at the institute a very secondary place due to its little efficiency», and he insisted instead that the biopsy was the most secure technique to formulate a diagnosis ${ }^{49}$.

\section{From local to national (and back again)}

Parallel to the creation of Roffo's anti-cancerous dispensaries, the municipality of Buenos Aires, through its main health authority, the Public Assistance, materialised a different conception of cancer organisation. Thus, in 1934, two new «Centres for the Diagnosis of Neoplasias» were opened to the public within the general hospitals «Rawson» and «Durand». Such inaugurations spurred on a heated discussion in the medical press over the convenience of a centralised or decentralised model of cancer diagnosis between a doctor of the IEM, who disparagingly labelled the initiative as «improvisations»,

48. Eraso, Yolanda. Managing uncertainty: Women and cancer in contemporary history. Reviews in History, IHR. 2012; review no. 1239. Available from: http://www.history.ac.uk/reviews/ review/1239. See also Eraso, n. 47; Teixeira, Luiz; Löwy llana. Imperfect tools for a difficult job: Colposcopy, 'colpocytology' and screening for cervical cancer in Brazil. Social Studies of Science. 2011; 41 (4): 585-608; Bryder, n. 41; and the article of Vanessa Lana in this dossier.

49. Roffo, Ángel. Memoria del Instituto de Medicina Experimental 1940-1943. Boletín del Instituto de Medicina Experimental para el Estudio y Tratamiento del Cáncer. 1943; 20: 13-669 (398). 
and the directors of the new centres ${ }^{50}$. The latter were two pathologists, who were associate professors of Anatomy and Physiological Pathology with a vast hospital experience in histopathologic diagnosis. In their response, they challenged the views of the IEM's members without concealing their irritation. One of them commented,

«The Public Assistance is perfectly equipped in its hospitals and institutes to treat those diseases [benign and malignant tumours]. It has skilful and illustrious radiotherapists; it has a valuable quantity of radium and numerous services with a group of eminent surgeons and specialists excessively able to perform brilliant treatments» 51 .

What was needed, they concluded, was to perform a timely and effective diagnosis. Interestingly, the diagnosis of cervical cancer provided the rationale for the creation of the centres and it became instrumental in the advocacy for a decentralised model of assistance. In the pathologists' response, it was Roffo's views on uterine cancer what was brought into consideration. They quoted a five-year report of the IEM's director in which out of 711 women diagnosed, only 23 (3.2\%) were operable cases, leading Roffo to insist in the importance of an early diagnosis as the only way to improve therapeutic results ${ }^{52}$.

As far as the availability of therapeutic resources is concerned - needed to any project of cancer decentralisation - to a great degree, pathologists' arguments proved true. Provincial and municipal governments became locally involved in the fight against cancer demonstrating different levels of commitment and financial support. The larger and richer cities, like Buenos Aires, concentrated the major number of efforts and monies as they lent support to fund various initiatives from Faculty specialists, many of whom were also politicians with intermittent participation at the Parliament or the local government, which certainly allowed some projects to prosper. In this sense, the availability of radium for cancer treatment was, in the case

50. Basso, Juan. La lucha contra el cáncer en el Instituto de Medicina Experimental de Buenos Aires. La Prensa Médica Argentina. 1935; 4: 192-196.

51. Mosto, Domingo. A propósito del artículo «La lucha contra el cáncer en el Instituto de Medicina Experimental de Buenos Aires» por el Dr Juan L. Basso. La Prensa Médica Argentina. 1935; 6: 286-289 (288).

52. Roffo, Ángel. Resultados del tratamiento del cáncer de matriz obtenidos en el Instituto en cinco años. Boletín del Instituto de Medicina Experimental para el Estudio y Tratamiento del Cáncer. 1930; 7 (24):123-129; and Mosto, n. 51, p. 289. 
of Buenos Aires, distributed between the Municipal Institute of Radiology and Physiotherapy inaugurated in 1931 and directed by a radiologist; and the National Institute of Radium of the Faculty of Medicine. The latter was annexed in 1936 to the Institute of Clinical Surgery («Hospital de Clínicas») to create an «anti-cancerous centre», an initiative of Dr José Arce, one of Argentina's most prestigious surgeons and chief representative of the Faculty's interests in the dispute with the Academy for the control of the IEM.

By the time the Director of the National Department of Hygiene outlined a national plan for the control of cancer in June 1941, the existing initiatives resembled a mosaic, a cluster of unrelated services in need of integration and re-orientation. The proposal of Dr Jacobo Spangenberg (1883-1969) contemplated the creation of a special division, the «Section of Neoplasias» with the aim of extending cancer diagnosis to the provinces and to act as the main state office for the control and supervision of cancer activities. He appointed Dr Juan E. Pessano as Director who was chiefly responsible for the elaboration of a national cancer plan. Almost a year later, and given the impression of an unforeseen addendum, Roffo was appointed as an «honorary consultant» to advise the director in the technical aspects of the Section. Notably, his role was rather nominal. The chosen name «Section of Neoplasias» indicated rather a continuation with the centres for the diagnosis of neoplasias instead of Roffo's cancer facilities («anti-cancerous dispensaries») ${ }^{53}$.

By the forties, the organisation of cancer in Argentina seemed to have entered a new era, at least from the impression given by the rapid sequence of events. The national state finally granted the disease with a special health division. The political turmoil that accompanied the appointment of Perón to the Presidency in 1946 left several medical institutes intervened, including the IEM. Roffo died the following year, while Pessano continued for few more years as responsible of the «Direction of Neoplasias» within the newly created Secretary of Public Health, with Ministry status. Yet the desired centralised direction of the health and welfare system that characterised the ambition of the new Secretary of Public Health, Dr Ramón Carrillo, was never accomplished, amongst other things because of the persistence of old and new fragmented structures. Indeed, the parliamentary debates

53. Ampliación de la lucha anticancerosa en el país. Boletín del Instituto de Medicina Experimental para el Estudio y Tratamiento del Cáncer. 1942; 19 (59): 321-338 (326-327). 
that took place before the creation of the National Direction of Public Health and Welfare (NDPH) in 1943, provide insight into the difficulties experienced in the past (through a range of unsuccessful bills and proposals) by a group of hygienists who endorsed the creation of a national health authority able to centralise all health care and welfare activities under a unified statutory structure. As we have seen specifically through the competing initiatives to organise cancer control, the broader perception at the time was that sanitary activities «have been for a long time resented because of the manifest autarchic tendency of the diverse institutions that in a 'disharmonious and isolated way' intensely have striven, but without satisfying general demands» ${ }^{54}$. Interestingly, the convenience of including cancer control within the functions of the centralised organisation (NDPH) was addressed by a Senator from Córdoba whose motion resulted in an article that made explicit the «fight against neoplasias, especially in relation to its early diagnosis» within the remit of the new institution ${ }^{55}$.

Yet the establishment of a national health authority able to integrate and coordinate the efforts of all the dispersed medical services and institutions under a unified front encountered two main stumbling blocks whose presence still have an impact today. The first one is embedded in the federal nature of the Argentinian government whose roots are set out in its National Constitution of 1853, and in the long-standing antagonism in the distribution of power between the provincial and national governments. The conflicts generated by federalism coupled in the forties with the second, and perhaps more influential, set of political problems: the ones emerging from the main social constituency that underpinned the political base of peronismo: the labour movement. Few months after the creation of the $\mathrm{NDPH}$, a separation with long-standing consequences took place when the welfare and medical assistance of workers left the jurisdiction of the NDPH to become dependent on the Secretary of Labour and Social Security that Perón controlled. This division, I propose following path-dependence notions, can be understood as a «critical juncture» a political moment in which a new path was set up, in this case, one that led to the raising of workers' health insurance funds (obras sociales) under the control of the trade unions, later institutionalised in 1970 to become the third major component

54. Creación de la Dirección Nacional de Salud Pública y Asistencia Social. Congreso Nacional. Cámara de Senadores. Diario de Sesiones, 22 Sept 1942. p. 338-390 (373).

55. Creación de la Dirección Nacional de Salud Pública, n. 54, p. 382. 
of the country's health system, alongside the public and the private sector provision. As a consequence, the Argentinian health system, as Susana Belmartino has observed, "gradually grew more varied and fragmented as each trade union developed its own health care service, or subcontracted it from the private sector, with little regulation or coordination by the state ${ }^{56}$. And, as the studies I mentioned in the introduction of this article have confirmed, these fragmented structures in the provision of health care are still being identified as one of the main problems to overcome. It seems that an analysis of its «reproductive mechanisms» in terms of pathdependence, which exceeds the scope of this article, could help explain why more recent attempts at implementing a national preventive programme in female cancer have so far been deflected.

\section{Conclusions}

Starting in the twenties, the first initiatives to organise the control of cancer in Argentina soon revealed the presence of different actors and interests: cancerologists, philanthropists, a socially-oriented cancer league, state authorities, hygienists and gynaecologists. It was the latter who, in the following decade, and with the support of the national universities, outlined a different approach for gynaecological cancers, and in so doing, questioned the nascent but powerful structures under which the fight against cancer was organised under the figure of Roffo and his model institute. In highlighting the way in which these actors positioned themselves, the different institutional models of cancer they envisioned (centralised and decentralised), and the political support they obtained from local authorities, I have drawn attention to the foundational ideas and actors that largely defined the fight against female cancer in the country. While examining the trajectory of these propositions I have often shifted from «cancer» to «female cancer» as the latter became a referent in the centralising $v s$ decentralising initiatives and polices. Remarkably, gynaecologists' unwavering resistance to gynaecological cancers to be absorbed by, or to become part of, the

56. Belmartino, Susana. The context and process of health care reform in Argentina. In: Fleury, Sonia; Belmartino, Susana; Baris, Enis, eds. Reshaping health care in Latin America. A comparative analysis of health care reform in Argentina, Brazil and Mexico. Ottawa: International Development Research Centre; 2000, p. 27-46 (30). 
general domain of «cancer disease» was grounded in their professional zeal brought by the degree of specialisation that gynaecology attained at the time. But above all, as I have tried to show here, it was in the field of cancer diagnosis, and especially in the uncontested field of the «early detection» culture where gynaecologists managed to stand out and assertively laid claim to gynaecological cancers.

Technology, I have argued, through a diagnostic tool like the colposcope was crucial in that process. Dr Pessano, the director of the «Direction of Neoplasias», published a handbook in 1947 entirely devoted to cancer diagnosis that was dedicated to general practitioners. The book was developed as a guide for diagnosis, not treatment, which reflects again, the way in which the former occupied the most outstanding place in the fight against the disease $\mathrm{e}^{57}$. The chapters on gynaecological cancers contained a detailed explanation on how to perform and interpret the technique of colposcopy, including an analysis of Hinselmann's classification of abnormal epithelium and a page of illustrations to guide their interpretation. The chapter concluded, in the same popular style in which the book was conceived, by admonishing doctors not «to think that it will be far from the time when colposcopy becomes a routine examination ${ }^{58}$. As it happened, colposcopy did become a technique of routine examination after the configuration of Argentina's health system post 1946. At the private practice, at the hospitals and clinics of obras sociales, and through the preventive campaigns organised by LALCEC, the practice of colposcopy somehow consolidated what the American Cancer Society famously called at the time «every physician's office [gynaecologist's in this case] a cancer detection centre» ${ }^{59}$. In this scenario, it is not surprising that the specialisation in female cancer loomed large. Since 1991, and against a background of medical oncologists, the Argentine Association of Gynaecological Oncology stands out as the only professional association of cancer that has been created according to bodyly organs.

Finally, I have drawn on ideas of path-dependence to help frame discussion about the competing foundational elements in the fight against female cancer. I have pointed to the window of opportunity that emerged around the years 1943-1946 when the political consensus to create a unified

57. Pessano, Esteban. Propósito. In: Cáncer. Inducción a su diagnóstico. Buenos Aires: Talleres gráficos P.R.O.C.M.O; 1947.

58. Pessano, n. 57, p. 296.

59. Aronowitz, n. 41, p. 215. 
national direction of health was soon rectified to develop a new path of fragmentation (worker's health insurance). In this way the contending and scattered cancer initiatives of the first decades of the century found, after those years, new forms of consolidation under the complex dynamics of the tri-partite nature of the Argentine health system.

While health professionals and policy-makers evaluate the statistics and health outcomes of specific policies and preventive programmes it would be equally relevant to develop a more grounded assessment of past health initiatives. Such an approach could at least alert them of the existence of a more detailed record of previous failures, provide elements to understand critically the historical constituency of fragmented experiences, and, above all -although this is a task to be thoroughly undertaken- help to understand, as in this instance, its iterative nature. 